\title{
IMPACTS OF GLOBAL AND LOCAL COVID-19 CASES ON EMERGING STOCK MARKETS
}

\section{KÜRESEL VE YEREL COVIDD-19 VAKALARININ GELISSMEKTE OLAN BORSALAR ÜZERINE ETKİSI}

\author{
M. Emir YÜCEL ${ }^{1}$, Özlem FIKIRLLi², Hasan ŞAHİN ${ }^{3}$
}
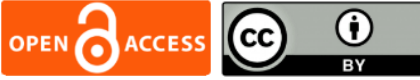

1. Arş. Gör. Dr., Bartın Üniversitesi, İktisadi ve İdari Bilimler Fakültesi, İktisat Bölümü,

myucel@bartin.edu.tr,

https://orcid.org/0000-0002-4003-7276

2. Arş. Gör., Ankara Üniversitesi, Siyasal Bilgiler Fakültesi, İktisat Bölümü,

ozlem_fikirli@ hotmail.com,

https://orcid.org/0000-0002-4003-7276

3. Prof. Dr., Ankara Üniversitesi, Siyasal Bilgiler Fakültesi, İktisat Bölümü,

hasansahin68@gmail.com,

https://orcid.org/0000-0001-5922-068X

\begin{tabular}{lr}
$\begin{array}{lr}\text { Makale Türü } \\
\text { Araştırma Makalesi }\end{array}$ & $\begin{array}{r}\text { Article Type } \\
\text { Research Article }\end{array}$ \\
Başvuru Tarihi & Application Date \\
10.04 .2021 & 04.10 .2021 \\
Yayına Kabul Tarihi & Admission Date \\
19.07.2021 & 07.19 .2021 \\
\multicolumn{2}{c}{ DOI } \\
\multicolumn{2}{c}{ https://doi.org/10.30798/makuiibf.912345 }
\end{tabular}

\begin{abstract}
In this study, we examine the both local and global Covid-19 deaths and confirmed cases impact on stock markets return. We use the daily data from 26 countries, which are classified as emerging financial markets. According to the findings, a decrease in emerging stock market returns is not only due to local confirmed cases, but also from global confirmed cases. Our analysis also suggests that while an increase in total confirmed cases within the local variables leads to more decrease, total deaths within the global variables cause more decline in returns. When we consider the change in the stock market returns brought about by both local and global level confirmed cases rates and death rates increase, all global level variables (new confirmed cases, total confirmed deaths, new confirmed cases) except total confirmed cases lead to more decline. In other words, even if the countries control the covid-19 locally, the negative global impact on the stock market will continue.
\end{abstract}

Keywords: Covid-19, Stock Market Returns, Emerging Markets, Pandemic.

$\ddot{O} z$

Bu çalıșma doğrulanmıș küresel ve yerel Covid-19 vaka sayılarının gelișmekte olan borsa getirileri üzerine etkisini incelemektedir. Çalışmada gelişmekte olan piyasa sınıflandırmasına giren 26 ülkeye ait günlük veriler kullanılmıştır. Elde edilen bulgular 1şı̆̆ında borsa getirilerinde yașanan düşüşler sadece yerel Covid-19 vakaları ile açıklanmamakta aynı zamanda küresel Covid-19 vakaları da bu düşüş̧te etkili olmaktadır.Analiz sonuçları ayrıca, yerel değiskenler içinde doğrulanmıs toplam vaka sayısında yaşanan artışın getiriler üzerinde en fazla azalmaya yol açtı̆ı̆ıı gösterirken, küresel değişkenlerde doğrulanmış toplam ölüm sayısının daha etkili olduğunu göstermektedir. Hem yerel hem de küresel düzeyde doğrulanmıș toplam vaka oranları ve ölüm oranları göz önüne alındığında, doğrulanmış toplam vaka değişkeni dışındaki küresel boyuttaki diğer tüm değiskenlerde (yeni vaka, toplam ölüm, yeni ölüm) yaşanan artış borsa getirileri üzerinde daha fazla negatif etkiye yol açmaktadır. Diğer bir ifadeyle ülkeler Covid-19 salgınını yerel boyutta kontrol altına alsalar bile, küresel olarak yaşanan artışlar borsa getirileri üzerinde olumsuz etkilere yol açmaktadır.

Anahtar Kelimeler: Covid-19, Borsa Getirileri, Gelişmekte Olan Piyasalar, Pandemi. 


\section{Çalışmanın Amacı}

\section{GENIŞLETILMIŞ ÖZET}

Çalışma, Morgan Stanley Capital tarafindan gelişmekte olan finansal piyasaya sahip 26 ülkenin en önemli borsa endeksi getirileri üzerinde doğrulanmış yerel ve küresel Covid-19 vaka sayılarının etkisinin incelenmesidir.

\section{Araştırma Soruları}

Covid-19 pandemisinin gelişmekte olan borsa getirileri üzerinde bir etkisi olmuş mudur? Eğer olmuşsa küresel dünyada bu etki sadece yerel boyutta yaşanan vaka sayıları ile açılanabilir mi ? Küresel vaka artışları gelişmekte olan piyasalarda daha fazla bir etkiye neden olabilir mi?

\section{Literatür Araştırması}

Covid-19, 1918 yaşanan influenza pandemisinden sonra dünyanın karşılaştığı en büyük salgın olabilir (Goodel, 2020). Ülkeler, Covid-19'un yayılmasını önlemek için yurtiçi ve yurtdışı seyahat kısıtlamaları, kapatmalar ve karantina önlemleri gibi bir dizi benzer önlem uygulamıştır. Bu özellikleri ile Covid-19, kısa sürede ekonomik bozulmaların daha açık gözlemlenebildiği finansal piyasalarda da hissedildi. Covid-19 salgınının ülke grupları veya ülkeler bazında borsa getirileri veya oynaklı̆̆ı üzerindeki etkisini inceleyen bir dizi çalışma kısa sürede ortaya çıkmıştır (Baig vd., 2021; Ali vd., 2020; Zhang vd., 2020; Topcu ve Gulal, 2020; Al-Awadhi vd., 2020; Alexakis vd., 2021; Haroon ve Rivzi, 2020; Salisu vd., 2020). Bu konudaki artan ilgiye rağmen, gelişmekte olan piyasaları analiz eden çok az çalışma vardır (Topcu ve Gulal, 2020; Haroon ve Rivzi, 2020; Salisu vd., 2020). Ayrıca literatürde sadece ülke tarafından doğrulanmış vakalar dikkate alınırken, dünyaca doğrulanmış vakalar görmezden gelinmiştir. Covid-19 salgınının gelişmekte olan piyasalar üzerindeki olumsuz etkisi, yapılan çalışmalarda açıkça ortaya konmaktadır. Gelişmekte olan piyasalar, gelişmiş piyasalara göre daha savunmasızdır (Salisu vd., 2020). Covid-19 salgını, Avrupa piyasalarına göre Asya piyasaları üzerinde daha fazla olumsuz etkiye sahip iken (Topcu ve Gulal, 2020), Covid-19 vakaları piyasalarda likidite sıkıntısına neden olmaktadır (Haroon ve Rivzi, 2020). Bunlara ek olarak Asraf (2020) gelişmekte olan piyasalar da dahil olmak üzere geniş örnekleminde Covid-19 doğrulanmış vakalar ile borsa getirileri arasında ters bir ilişki bulmuştur.

\section{Yöntem}

Küresel ve yerel Covid-19 doğrulanmış vaka sayılarının gelişmekte olan ülkeler üzerindeki etkisi örneklem kapsamında yer alan ülkelerin borsa endekslerinin işlem gördüğü açık günlerin 2 Ocak 2020 ve 25 Eylül 2020 arasındaki tüm verilerini kapsayan dengesiz panel veri yapısı ile incelenmiştir. Analiz dahilinde oluşturulan 8 farklı modelde yatay kesit bağımlılığı tespit edildiği için birim yatay kesit bağımlılı̆̆ını dikkate alan ve dengesiz panel veri yapısına uygun 3 farklı birim kök testi prosedürü uygulanmıştır. Yapılan testler sonucunda Driscoll-Kraay standart hataları altında sabit etkiler tahmin yöntemi kullanılmıştır. 


\section{Sonuç ve Değerlendirme}

Tahmin sonuçlarından elde edilen bulgulara göre gelişmekte olan borsa getirilerindeki düşüşün; a) hem yerel hem de küresel olarak doğrulanmış vakalardan etkilenmektedir, b) doğrulanmış toplam vakalardaki artış oranının etkisi yerel boyutta daha büyüktür; c) ölüm değişkeninin etkisi küresel ölçekte daha yüksektir. Ayrıca, doğrulanmış toplam vaka sayısındaki artış oranının, doğrulanmış yeni vaka sayısındaki artış hızından hem küresel hem de yerel olarak daha etkili olduğu sonucu elde edilmiştir. $\mathrm{Bu}$ nedenlerle, regresyon modellerinde yalnızca yerel olarak doğrulanmış vakaların kullanılması doğru bir tahmin yapmaktan uzak olacaktır. Yerel ve küresel düzeydeki vaka artışlarından dolayı yaşanan borsa getirilerindeki düşüşü karşılaştırdığımızda, doğrulanmış toplam vakalar hariç küresel düzeydeki değişkenlerdeki artış, borsa getirilerinde daha fazla düşüşe yol açmaktadır. Dolayısıyla ülkeler Covid19 'u yerel olarak kontrol altına alsa bile Covid-19'un borsa getirileri üzerindeki olumsuz etkileri devam edecektir. Sonuç olarak ülkeler, tüm dünyada Covid-19 önlemlerinin alınması konusunda 1srar etmeli ve Covid-19 önlemleri konusunda işbirliğinin hayati öneminin altını çizmelidir. 


\section{INTRODUCTION}

Approximately 4 months after the coronavirus disease (Covid-19) appeared in Wuhan, China in December-2019, 1 million people worldwide had symptoms of the disease, and this figure exceeded 3.5 million people after just 1 month. The rapid spread of the novel coronavirus (Covid-19) and the fear it created in the world has caused a panic in the global economy. So much so that this fear can be expressed as the biggest fear that financial and economic systems have ever experienced (Phan and Narayan, 2020).

Covid-19 may be the biggest pandemic the world has faced after the influenza pandemic of 1918 (Goodel, 2020). Countries implemented a number of similar measures to prevent the spread of Covid19 , such as domestic and international travel restrictions, lockdowns, and quarantine measures. With these features, Covid-19 has been felt in financial markets where economic distortions can be observed in a short time. There is a growing literature that examines the impact of the Covid-19 outbreak on stock market returns or volatility by country groups or countries (Baig et al., 2021; Ali et al., 2020; Zhang et al., 2020; Topcu and Gulal, 2020; Al-Awadhi et al., 2020; Alexakis et al., 2021; Haroon and Rivzi, 2020; Salisu et al., 2020). Despite of increasing interest on this issue, there is few studies analyzed emerging markets (Topcu and Gulal, 2020; Haroon and Rivzi, 2020; Salisu et al., 2020). In addition, while only country confirmed cases were taken into account in literature, world confirmed cases were ignored. Unlike most of the both country groups and country-based studies, in this study we did not only consider country confirmed cases, but also included world confirmed cases in the analysis. Thus, this study closes an important gap in the literature.

Strong negative correlation between stock returns and countries' Covid-19 confirmed cases is observed in many countries (Ashraf, 2020). Our study investigates the impact of the both global and local dimension of the Covid-19 pandemic on stock market returns over a wide period of time. Especially in emerging markets, the downward trend in stock markets started with both local and global confirmed cases increases. Fig.1 shows the emerging market average stock market index and Fig.2 shows emerging market and world total confirmed cases which account for each emerging market as world total confirmed cases minus emerging market's total case, in the logarithmic scale. The sharp decline in stock market indices after the end of February and the increase in the rate of increase in local and global confirmed cases coincide with the same period. For this reason, the decrease may be due not only to local confirmed cases but also to global confirmed cases. 
Figure 1. Average of Emerging Stock Markets Indices (2 January 2020=100)

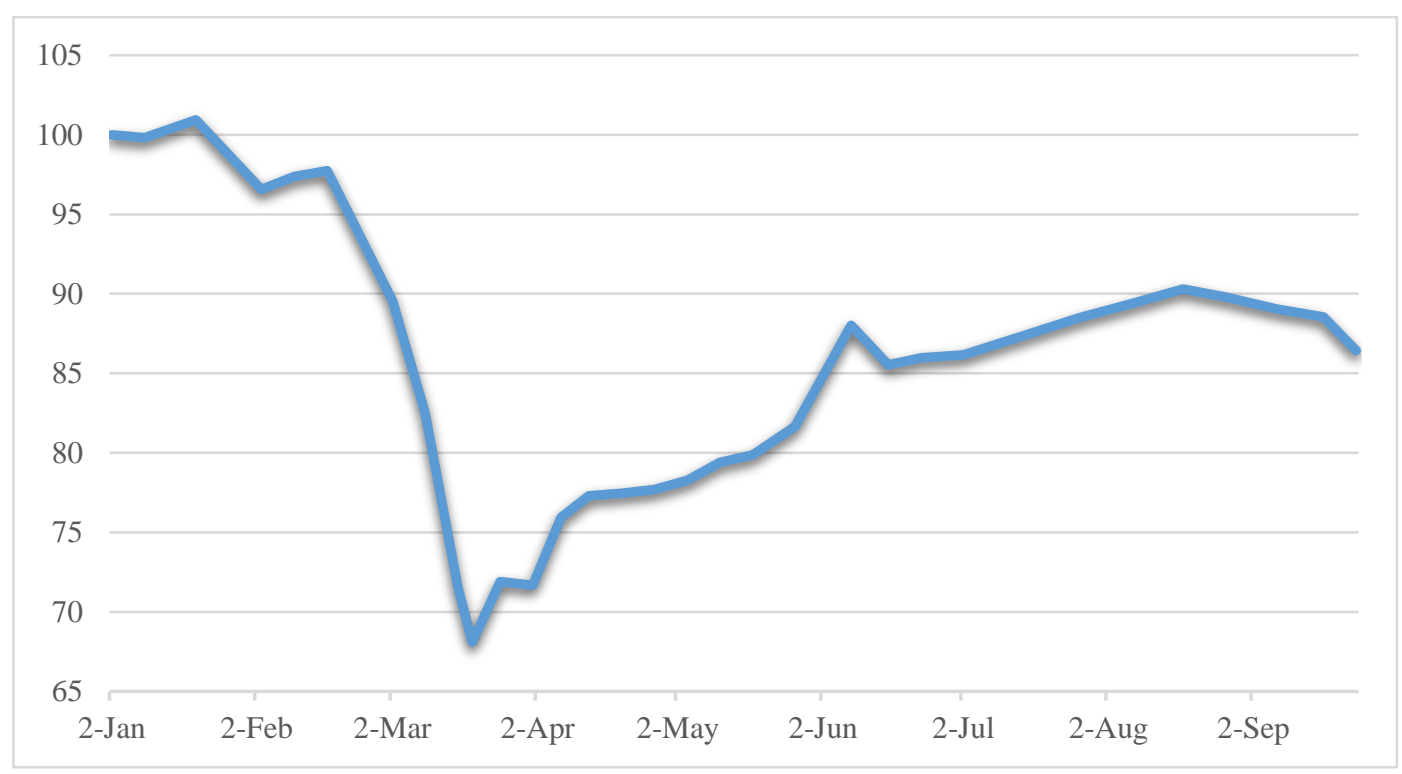

Figure 2. Emerging Markets and World Total Confirmed Cases

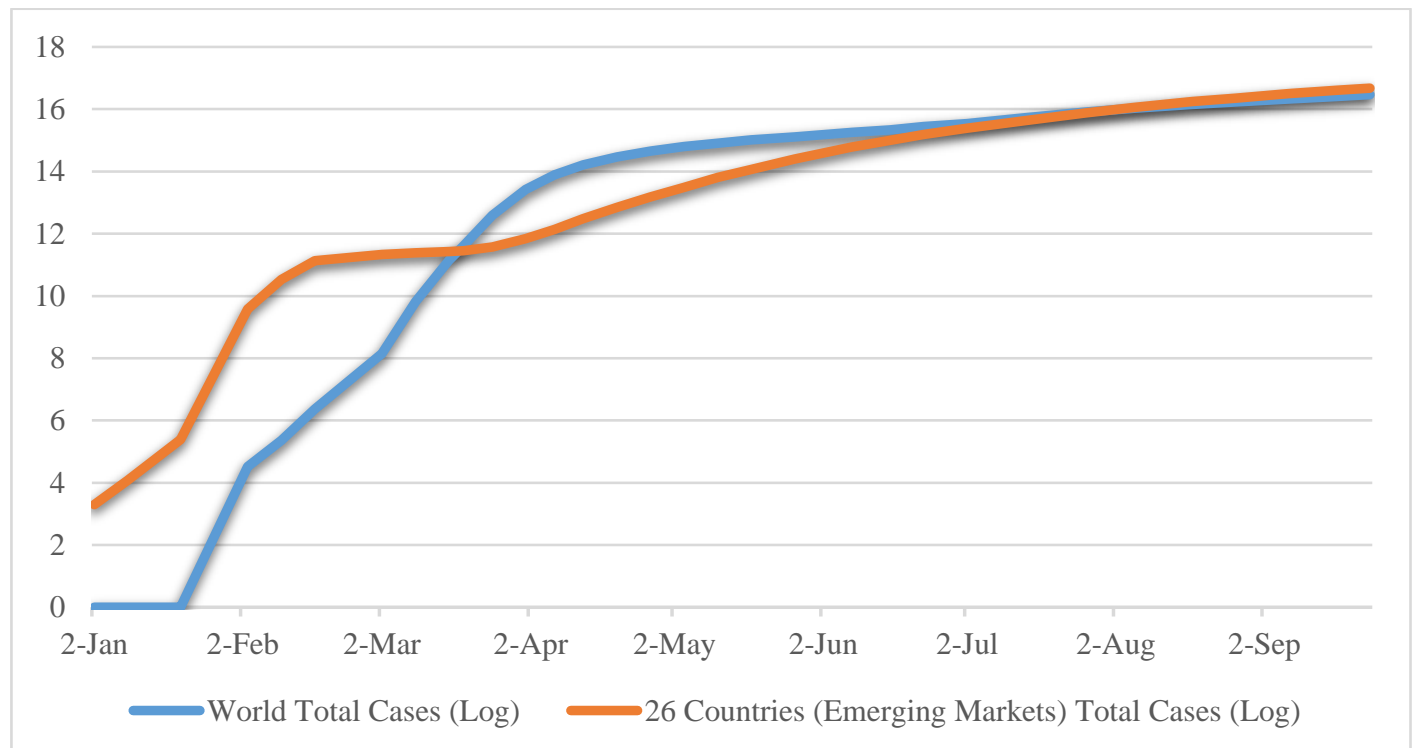

Note: World total confirmed cases is defined as the world total confirmed cases minus the total confirmed cases of 26 countries.

The negative impact of the Covid-19 pandemic on emerging markets is clearly shown in studies. Emerging markets are more vulnerable to the negative effects of Covid-19 (Salisu et al., 2020). The Covid-19 pandemic has a higher negative impact on emerging Asian markets compared to emerging European markets (Topcu and Gulal, 2020) and an increase in the number of Covid-19 confirmed cases causes liquidity shortage in the markets (Haroon and Rivzi, 2020). In addition to them, Asraf (2020) also finds an inverse relationship between Covid-19 confirmed cases and market returns in its large sample, including emerging markets. For this reason, all data on the days when all emerging markets are open are included in the analysis. This approach aims to fill another gap that is lacking in the literature. 


\section{DATA AND METHODOLOGY}

We use a panel data approach to examine the effect of the Covid-19 outbreak on emerging markets return. Our specification is as follows;

$$
\begin{aligned}
& s m r_{i t}=\beta_{0}+\beta_{1} \text { Covid } 19_{i, t-1}+\beta_{2} \log (\text { exchange })_{i, t}+\beta_{3} c p i_{i, t}+\varepsilon_{i, t} \\
& \text { where } \mathrm{i}=1,2, \ldots \ldots, 26 \text { and } \mathrm{t}=02.01 .2020, \ldots \ldots, 15.10 .2020
\end{aligned}
$$

In Eqs(1) $\beta_{0}, \beta_{1}, \beta_{2}$ and $\beta_{3}$ represent unknown parameters and $\varepsilon_{i, t}$ is the error term . Where $s m r_{i, t}$ is calculated as logarithmic differences of daily stock market indices, $\operatorname{smr}_{\mathrm{i}, \mathrm{t}}=100 *\left(\log \left(\operatorname{Index}_{\mathrm{i}, \mathrm{t}}\right)\right.$ $\left.\log \left(\operatorname{Index}_{\mathrm{i}, \mathrm{t}-1}\right)\right)$. Log(exchange) is the logarithmic USD exchange rate and cpi refers to the consumer price index set to be 100 for January 2020. In the analysis, we use 8 different Covid-19 measures. 1) country specific total confirmed cases, 2) country specific total deaths, 3) country specific new confirmed cases, 4) country specific new deaths, 5) world total confirmed cases without related country 6) world total deaths without related country, 7) world new confirmed cases without related country, 8) world new deaths without related country. We take the logarithmic difference of all Covid-19 variables and also added 1 to all observations avoid taking the logarithm of zero. To eliminate a possible trend effect, a trend variable is used in the estimation.

The data used in the study, which analyses the impact of the Covid-19 outbreak on emerging stock markets, starts at 02.01.2020 and ends at 25.09.2020. When deciding on the list of countries to be included in the sample, we considered the emerging markets list presented by Morgan Stanley Capital and downloaded both stock market indices and exchange rate daily data from www.investing.com web site over the this period. We use only one major stock market index data from each country and used the national currency per US dollar for exchange rate data. We obtained CPI data, another control variable that we use together with the exchange rate, on a monthly basis from the International Monetary Fund (IMF) database. We also obtained daily data of 8 different Covid-19 variables - both new and cumulative daily country specific/world confirmed cases and deaths- that we used in the analysis extracted from public GitHub repository, Our World in Data COVID-19 database (https://github.com/owid/covid-19-data/tree/master/public/data).

Due to the different lockdown dates and the inclusion of Islamic countries - whose stock markets are closed on Friday and open to transaction on Sunday- in the analysis, the data were arranged in an unbalanced panel format. Since the unbalanced panel format minimizes observation losses, the impact of Covid-19 confirmed cases on stock market indexes can be investigated more clearly. Thus, we included 4753 observations from 26 emerging markets (Argentina, Brazil, Chile, China, Colombia, Czech Republic, Egypt, Greece, Hungary, India, Indonesia, Korea, Malaysia, Mexico, Pakistan, Peru, Philippines, Poland, Qatar, Russia, Saudi Arabia, South Africa, Taiwan, Thailand, Turkey, United Arab Emirates) from January 2, 2020 to September 25, 2020 into the analysis. Since the first case was 
officially announced by the Chinese government in December 2019 (WHO, 2020), the starting date of the data is January 2, 2020.

\section{FINDINGS}

Table 1 provides descriptive statistics for all the variables used in the study. On average, the daily logarithmic stock return is \%-0.084, which is what we expect due to the pandemic for negative sign and long-run convergence to zero hypothesis. In addition to negative average daily logarithmic stock return, the minimum value is -16.069 with 2.106 standard deviation. The mean of all Covid-19 variables except c_newdeath -which is a positive value very close to zero- is positive.

Table 1. Descriptive Statistics

\begin{tabular}{lcccccccc}
\hline Variables & Observations & Mean & Median & SD & Max & Min & Skewness & Kurtosis \\
\hline smr & 4727 & -0.084 & 0.032 & 2.106 & 13.023 & -16.069 & -1.287 & 13.325 \\
log(exchange) & 4753 & 3.498 & 3.120 & 2.342 & 9.711 & -0.177 & 0.889 & 3.164 \\
cpi & 4753 & 100.634 & 100.278 & 2.584 & 119.594 & 96.117 & 3.574 & 22.233 \\
C_totalcase & 4727 & 0.001 & 0.011 & 0.911 & 3.332 & -15.561 & -13.177 & 187.183 \\
C_totaldeath & 4727 & 0.0004 & 0.004 & 0.636 & 2.829 & -11.842 & -13.719 & 208.294 \\
C_newcase & 4727 & 0 & 0 & 1.254 & 9.091 & -11.368 & -1.051 & 19.125 \\
C_newdeath & 4727 & -0.0002 & 0 & 0.892 & 7.163 & -7.163 & -0.695 & 11.827 \\
W_totalcase & 4727 & 0.003 & 0.021 & 1.231 & 4.094 & -17.281 & -12.749 & 175.553 \\
W_totaldeath & 4727 & 0.003 & 0.019 & 1.014 & 3.504 & -13.793 & -13.164 & 179.263 \\
W_newcase & 4727 & 0.002 & 0.057 & 1.376 & 7.944 & -13.286 & -3.792 & 40.587 \\
W_newdeath & 4727 & 0.002 & 0.089 & 1.1 & 4.219 & -9.411 & -2.698 & 23.191 \\
\hline
\end{tabular}

Notes: smr is the daily stock return(log-difference), cpi is the consumer price index(monthly). C_totalcase is the country spesific total case(log-difference), C_totaldeath is the country spesific total death(log-difference), C_newcase is the country spesific new case(log-difference), C_newdeath country spesific new death(log-difference), W_totalcase is the world total case without related country(log-difference), W_totaldeath is the world total death without related country(log-difference), W_newcase is the world new case without related country(log-difference), W_newdeath is the world new death without related country(log-difference).

Table 2 shows the pairwise correlations between all variables included in the study. There is a negative correlation between stock returns and Covid-19 variables, and this correlation is highest with the c_totalcase variable in the absolute term and the least with the c_newdeath variable. In addition, there is a positive correlation between Covid-19 variables as expected.

Table 2. Correlation Matrix

\begin{tabular}{|c|c|c|c|c|c|c|c|c|c|c|c|c|}
\hline & & 1 & 2 & 3 & 4 & 5 & 6 & 7 & 8 & 9 & 10 & 11 \\
\hline 1 & smr & 1.000 & & & & & & & & & & \\
\hline 2 & log(exchange) & -0.003 & 1.000 & & & & & & & & & \\
\hline 3 & CPI & 0.011 & 0.101 & 1.000 & & & & & & & & \\
\hline 4 & C_totalcase & -0.187 & 0.009 & -0.002 & 1.000 & & & & & & & \\
\hline 5 & C_totaldeath & -0.005 & 0.021 & 0.010 & 0.441 & 1.000 & & & & & & \\
\hline 6 & C_newcase & -0.069 & 0.002 & 0.001 & 0.321 & 0.205 & 1.000 & & & & & \\
\hline 7 & C_newdeath & -0.012 & 0.003 & 0.004 & 0.148 & 0.314 & 0.624 & 1.000 & & & & \\
\hline 8 & W_totalcase & -0.065 & -0.005 & -0.057 & 0.131 & 0.095 & 0.071 & 0.057 & 1.000 & & & \\
\hline 9 & W_totaldeath & -0.067 & -0.003 & -0.086 & 0.225 & 0.162 & 0.113 & 0.088 & 0.428 & 1.000 & & \\
\hline 10 & W_newcase & -0.113 & -0.001 & -0.012 & 0.178 & 0.160 & 0.468 & 0.463 & 0.349 & 0.310 & 1.000 & \\
\hline 11 & W_newdeath & -0.095 & -0.001 & -0.009 & 0.192 & 0.167 & 0.551 & 0.553 & 0.203 & 0.403 & 0.797 & 1.000 \\
\hline
\end{tabular}


Notes: smr is the daily stock return(log-difference), cpi is the consumer price index(monthly). C_totalcase is the country spesific total case(log-difference), C_totaldeath is the country spesific total death (log-difference), C_newcase is the country spesific new case(log-difference), C_newdeath country spesific new death(log-difference), W_totalcase is the world total case without related country(logdifference), W_totaldeath is the world total death without related country

Table 3 shows the results of the Breusch Pagan Lagrange Multiplier (1980) and Pesaran (2004) cross-section dependence test, which can be used in the case of $\mathrm{T}>\mathrm{N}$ and unbalanced panels. For all estimated models, with all zero p-value, we reject the null hypothesis of cross-section independence. For this reason, we used unit root tests procedure that takes into account the cross-sectional dependency. We considered ADF (Augmented Dickey Fuller) and PP (Phillips-Perron) based Fisher unit root test proposed by Maddala and $\mathrm{Wu}$ (1999) and Choi (2001), which is suitable to the unbalanced panel data format. If the cross-section means are subtracted from the series, this test procedure gives consistent results under cross-section dependence. As shown in Table 4, we reject the null hypothesis unit root process for all variables - except C_totalcase PESCADF trend and constant statistic - at \%1 significant level. Based on result provided in Table 3 and Table 4, we estimate fixed effects models with DriscollKraay (1998) robust standard errors. Those estimation results are in Table 5 and Table 6.

Table 3. Cross-Section Dependence Tests

\begin{tabular}{lcccc}
\hline Models & $\begin{array}{c}\text { Breush-Pagan LM } \\
\text { Statistic }\end{array}$ & P-Value & CD-Test Statistic & P-Value \\
\hline Model 1 & $2946.183^{* * *}$ & 0.000 & $32.501 * * *$ & 0.000 \\
Model 2 & $2996.937 * * *$ & 0.000 & $32.879 * * *$ & 0.000 \\
Model 3 & $2477.83 * * *$ & 0.000 & $25.781 * * *$ & 0.000 \\
Model 4 & $3006.424 * * *$ & 0.000 & $33.147 * * *$ & 0.000 \\
Model 5 & $2929.13^{* * *}$ & 0.000 & $33.093 * * *$ & 0.000 \\
Model 6 & $2925.782^{* * *}$ & 0.000 & $32.756 * * *$ & 0.000 \\
Model 7 & $3018.132 * * *$ & 0.000 & $33.218^{* * *}$ & 0.000 \\
Model 8 & $3027.238^{* * *}$ & 0.000 & $33.369 * * *$ & 0.000 \\
\hline
\end{tabular}

Notes: 1) *** Indicates rejection of the null hypothesis at the $1 \%$ significance level. 2) Model 1,2,3,4 and models 5,6,7,8 refers to estimated models in Table 5 and Table 6 respectively.

Table 4. Unit Root Tests

\begin{tabular}{|c|c|c|c|c|c|c|}
\hline Variables & $\begin{array}{r}\text { Fisher ADF } \\
\text { ( Constant) }\end{array}$ & $\begin{array}{c}\text { Fisher ADF } \\
\text { (Trend and } \\
\text { Constant) }\end{array}$ & $\begin{array}{l}\text { Fisher PP } \\
\text { (Constant) }\end{array}$ & $\begin{array}{c}\text { Fisher ADF } \\
\text { Trend and } \\
\text { Constant }\end{array}$ & $\begin{array}{c}\text { PESCADF } \\
\text { intercept }\end{array}$ & $\begin{array}{c}\text { PESCADF } \\
\text { Trend and } \\
\text { Constant }\end{array}$ \\
\hline \multirow{2}{*}{ (1) $\mathrm{smr}$} & $186.419 * * *$ & $193.973 * * *$ & $240.184 * * *$ & $233.749 * * *$ & $-18.089^{* * *}$ & $-16.633^{* * * *}$ \\
\hline & $(0.000)$ & $(0.000)$ & $(0.000)$ & $(0.000)$ & $(0.000)$ & $(0.000)$ \\
\hline \multirow{2}{*}{ (2) log_exchange } & $14.020 * * *$ & $15.570 * * *$ & $24.237 * * *$ & $25.775 * * *$ & $-4.372 * * *$ & \multirow{2}{*}{$\begin{array}{c}-2.527 * * * \\
(0.006)\end{array}$} \\
\hline & $(0.000)$ & $(0.000)$ & $(0.000)$ & $(0.000)$ & $(0.000)$ & \\
\hline \multirow{2}{*}{ (4) $C_{-}$totalcase } & $41.913 * * *$ & $36.090 * * *$ & $57.514 * * *$ & $57.086^{* * *}$ & $-4.407 * * *$ & $-2.183 * *$ \\
\hline & $(0.000)$ & $(0.000)$ & $(0.000)$ & $(0.000)$ & $(0.000)$ & $(0.015)$ \\
\hline \multirow{2}{*}{ (5) $C_{-}$totaldeath } & $46.130 * * *$ & $39.750 * * *$ & $82.877 * * *$ & $48.563 * * *$ & $-12.912 * * *$ & $-11.988 * * *$ \\
\hline & $(0.000)$ & $(0.000)$ & $(0.000)$ & $(0.000)$ & $(0.000)$ & $(0.000)$ \\
\hline
\end{tabular}




\begin{tabular}{|c|c|c|c|c|c|c|}
\hline (6) C_newcase & $\begin{array}{c}124.800 * * * \\
(0.000)\end{array}$ & $\begin{array}{c}127.430 * * * \\
(0.000)\end{array}$ & $\begin{array}{c}85.326^{* * * *} \\
(0.000)\end{array}$ & $\begin{array}{c}73.557 * * * \\
(0.000)\end{array}$ & $\begin{array}{c}-20.107 * * * \\
(0.000)\end{array}$ & $\begin{array}{c}-19.053 * * * \\
(0.000)\end{array}$ \\
\hline \multirow{2}{*}{ (7) $C_{-}$newdeath } & $206.930 * * *$ & $198.970 * * *$ & $49.797 * * *$ & $46.801 * * *$ & $-23.734 * * *$ & $-23.502 * * *$ \\
\hline & $(0.000)$ & $(0.000)$ & $(0.000)$ & $(0.000)$ & $(0.000)$ & $(0.000)$ \\
\hline \multirow{2}{*}{ (8) W_totalcase } & $34.740 * * *$ & $36.420 * * *$ & $48.610^{* * *}$ & $49.217 * * *$ & $-6.604 * * *$ & $-3.682 * * *$ \\
\hline & $(0.000)$ & $(0.000)$ & $(0.000)$ & $(0.000)$ & $(0.000)$ & $(0.000)$ \\
\hline \multirow{2}{*}{ (9) W_totaldeath } & $31.860 * * *$ & $33.330 * * *$ & $48.563 * * *$ & $49.106^{* * * *}$ & $-9.740 * * *$ & $-7.756 * * *$ \\
\hline & $(0.000)$ & $(0.000)$ & $(0.000)$ & $(0.000)$ & $(0.000)$ & $(0.000)$ \\
\hline \multirow{2}{*}{ (10) W_newcase } & $46.960 * * *$ & $58.710 * * *$ & $42.909 * * *$ & $41.865^{* * * *}$ & $-24.655 * * *$ & $-24.675 * * *$ \\
\hline & $(0.000)$ & $(0.000)$ & $(0.000)$ & $(0.000)$ & $(0.000)$ & $(0.000)$ \\
\hline \multirow{2}{*}{ (11) W_newdeath } & $48.100 * * *$ & $72.050 * * *$ & $46.697 * * *$ & $43.902 * * *$ & $-24.290 * * *$ & $-24.533 * * *$ \\
\hline & $(0.000)$ & $(0.000)$ & $(0.000)$ & $(0.000)$ & $(0.000)$ & $(0.000)$ \\
\hline
\end{tabular}

Notes: 1) ****, **** Indicates rejection of the null hypothesis at the 1\%,\%5, \%10 significance level respectively. 2) Because of the number of observations in cpi variable is monthly and insufficient, unit root tests don't perform.

In examining the impact of the Covid-19 pandemic on the returns of emerging stock markets, we analyze the effects of country-specific and world data separately. According to the estimation results, we find a negative effect of the increase in cpi on stock returns, while the increase in exchange rate had a positive effect in all estimated models. Table 5 shows the results of the fixed effect models applied to country specific Covid-19 variables. Country based Covid-19 coefficients - except c_newdeath - have a negative effect on stock market returns as expected.

Table 5. Country Specific Covid-19 Variables FE Estimation with Driscoll-Kraay Robust Standard Errors

\begin{tabular}{|c|c|c|c|c|}
\hline & Model 1 & Model 2 & Model 3 & Model 4 \\
\hline \multirow{2}{*}{ cpi } & $-0.0433 * *$ & $-0.0489 * *$ & $-0.0467 * *$ & $-0.0461 * *$ \\
\hline & $(0.0218)$ & $(0.0221)$ & $(0.022)$ & $(0.0221)$ \\
\hline \multirow{2}{*}{ log_exchange } & $4.7448 * * *$ & $4.0339 * * *$ & $3.7169 * * *$ & $3.6682 * * *$ \\
\hline & $(0.661)$ & $(0.6817)$ & $(0.6632)$ & $(0.665)$ \\
\hline \multirow{2}{*}{ C_totalcase } & $-1.818^{* * *}$ & & & \\
\hline & $(0.1418)$ & & & \\
\hline \multirow{2}{*}{ C_totaldeath } & & $-0.4947 * *$ & & \\
\hline & & $(0.2005)$ & & \\
\hline \multirow{2}{*}{ C_newcase } & & & $-0.118 * * *$ & \\
\hline & & & $(0.0245)$ & \\
\hline \multirow{2}{*}{ C_newdeath } & & & & -0.036 \\
\hline & & & & $(0.0329)$ \\
\hline Cross-Sections & 26 & 26 & 26 & 26 \\
\hline Observations & 4727 & 4727 & 4727 & 4727 \\
\hline Wald Statistics (Chi-Sq) & $224.601 * * *$ & $63.373^{* * *}$ & $80.751^{* * *}$ & $58.286^{* * * *}$ \\
\hline
\end{tabular}

Notes: 1) $* * * *, * * *$ Indicates rejection of the null hypothesis at the $1 \%, \% 5, \% 10$ significance level respectively. 2) Standard errors in parenthesis and adjusted for cross-sectional dependence. 3) Wald test null hypothesis is all coefficients are jointly zero. 4) All Covid-19 variables are in the logarithmic difference form. 5) A trend variable is used in all estimations. 
Table 6. World Covid-19 Variables FE Estimation with Driscoll-Kraay Robust Standard Errors

\begin{tabular}{|c|c|c|c|c|}
\hline & Model 5 & Model 6 & Model 7 & Model 8 \\
\hline \multirow{2}{*}{ cpi } & $-0.0384 *$ & $-0.0401 *$ & $-0.0432 * *$ & $-0.0446^{* *}$ \\
\hline & $(0.0222)$ & $(0.0221)$ & $(0.0219)$ & $(0.022)$ \\
\hline \multirow{2}{*}{ log_exchange } & $3.4137 * * *$ & $3.4957 * * *$ & $3.5718^{* * * *}$ & $3.6303 * * *$ \\
\hline & $(0.6683)$ & $(0.6659)$ & $(0.6614)$ & $(0.6611)$ \\
\hline \multirow{2}{*}{ W_totalcase } & $-0.4258 * * *$ & & & \\
\hline & $(0.1039)$ & & & \\
\hline \multirow{2}{*}{ W_totaldeath } & & $-0.7801 * * *$ & & \\
\hline & & $(0.1859)$ & & \\
\hline \multirow{2}{*}{ W_newcase } & & & $-0.2145 * * *$ & \\
\hline & & & $(0.0005)$ & \\
\hline \multirow{2}{*}{ W_newdeath } & & & & $-0.2006^{* * *}$ \\
\hline & & & & $(0.0303)$ \\
\hline Cross-Sections & 26 & 26 & 26 & 26 \\
\hline Observations & 4727 & 4727 & 4727 & 4727 \\
\hline Wald Test (Chi-Sq Stat) & $74.141^{* * *}$ & $74.990^{* * * *}$ & $122.344 * * *$ & $101.450^{* * *}$ \\
\hline
\end{tabular}

Notes: 1) $* * * *, * * *$ Indicates rejection of the null hypothesis at the $1 \%, \% 5, \% 10$ significance level respectively. 2) Standard errors in parenthesis and adjusted for cross-sectional dependence. 3) Wald test null hypothesis is all coefficients are jointly zero. 4) All Covid-19 variables are in the logarithmic difference form. 5) A trend variable is used in all estimations.

As the estimation results clearly show, all Covid-19 variables except the c_newdeath variable have a negative and significant effect (\%1 level) on stock returns. $\% 1$ increase in local total confirmed cases, local total death, local new confirmed cases and local new death reduce stock market returns $\% 1.818, \% 0.4947, \% 0.118, \% 0.036$ respectively. Namely, change in the country total case (C_totalcase) variable result in the highest negative alteration on stock market returns within the scope of the sample. Also, at local levels, the increase in total deaths lead to more decrease than new confirmed cases and new death.

Table 6 reports effects of the global Covid-19 variables on stock market returns. The increase in global Covid-19 variables negatively affects the rate of return. \%1 increase in global total confirmed cases, global total death, global new confirmed cases and global new death reduce stock market returns $\% 0.4258, \% 0.7801, \% 0.2145, \% 0.2006$ respectively. The increase of total variables leads to more decline, as in local variables estimation. However, contrary to the local case results, the increase in the rate of total death create more decline than increase in the rate of total case rate. In addition, the global new death variable also shows a statistically significant result. When we consider the change in the stock market returns brought about by both local and global level variables increase, all global level variables except total confirmed cases lead to more decline. In other words, even if the countries get under control the covid-19 locally, the negative global impacts on the stock market will continue. 


\section{CONCLUSION}

The aim of this study is to analyze the global and local dimensions of the Covid-19 pandemic in 26 emerging markets by using a data set running from January 2nd, 2020 and September 25th, 2020. We use fixed effects model with Driscoll-Kraay robust standard errors. According to the estimation results we find that the decrease in stock market returns is; a) affected by both local and global confirmed cases; b) the effect of the rate of increase in total confirmed cases is greater in the local variable; c) effect of the death variable is higher globally. We also observe that the rate of increase in the total number of confirmed cases is more effective both globally and locally than the rate of increase in the number of new confirmed cases. For these reasons using only local confirmed cases in regression models will be far from making an accurate estimate.

When we compare the stock market returns decline which result from local and global level variables increase, increase in global level variables excluding total confirmed cases lead to more decrease in the stock market returns. So, negative effects of Covid-19 on stock markets will continue even though countries overcome the Covid-19 locally. Consequently, countries should insist on taken Covid-19 measures all around the world and underlie the cruciality of the cooperation about the Covid19 measures.

Scope of this study is bounded with emerging stock markets. Hence, global effects of Covid-19 on advanced stock markets have been unclear and investigate of these effects are important for determine the global Covid-19 effects more explicit. In advanced stock markets, if there is a global Covid-19 effect we can talk about the Covid-19 measures forced by international organizations.

\section{REFERENCES}

Al-Awadhi, A. M., Al-Saifi, K., Al-Awadhi, A., and Alhamadi, S. (2020). Death and contagious infectious diseases: Impact of the COVID-19 virus on stock market returns, Journal of Behavioral and Experimental Finance,27, 100326. https://doi.org/10.1016/j.jbef.2020.100326

Alexakis, C., Eleftheriou, K., and Patsoulis, P. (2021). COVID-19 containment measures and stock market returns: An international spatial econometrics investigation, Journal of Behavioral and Experimental Finance, 29, 100428. https://doi.org/10.1016/j.jbef.2020.100428

Ali, M., Alam, N., and Rizvi, S. A. R. (2020). Coronavirus (COVID-19)-An epidemic or pandemic for financial markets, Journal of Behavioral and Experimental Finance, 27, 100341. https://doi.org/10.1016/j.jbef.2020.100341

Ashraf, B. N. (2020). Stock markets' reaction to COVID-19: cases or fatalities? . Research in $\begin{array}{lllll}\text { International Business and Finance, } & \end{array}$ https://doi.org/10.1016/j.ribaf.2020.101249

Baig, A.S., Butt, H.A., Haroon, O. and Rizvi, S.A.R. (2021). Deaths, panic, lockdowns and US equity markets: The case of COVID-19 pandemic, Finance Research Letters, 38, 101701. https://doi.org/10.1016/j.frl.2020.101701 
Breusch, T. S., and Pagan, A. R. (1980). The Lagrange multiplier test and its applications to model specification in econometrics, The Review of Economic Studies, 47(1), 239-253.

Choi, I. (2001). Unit root tests for panel data, Journal of international money and Finance, 20(2), 249-272.

Goodell, J. W. (2020). Covid-19 and finance: Agendas for future research, Finance Research Letters, 35, 101512. https://doi.org/10.1016/j.frl.2020.101512

Haroon, O., and Rizvi, S. A. R. (2020). Flatten the curve and stock market liquidity-an inquiry into emerging economies. Emerging Markets Finance and Trade, 56(10), 2151-2161. https://doi.org/10.1080/1540496X.2020.1784716

Investing, 2020. Investing Data. Investing.com, Nocosia, Cyprus.

Maddala, G. S., and Wu, S. (1999). A comparative study of unit root tests with panel data and a new simple test. Oxford Bulletin of Economics and statistics, 61(S1), 631-652.

Pesaran, H. M. (2004). General diagnostic tests for cross-sectional dependence in panels, University of Cambridge, Cambridge Working Papers in Economics, 435.

Phan, D.H.B. and Narayan, P.K. (2020). Country responses and the reaction of the stock market to COVID-19-a preliminary exposition, Emerging Market Finance and Trade, https://doi.org/10.1080/1540496X.2020.1784719

Salisu, A. A., Sikiru, A. A., and Vo, X. V. (2020). Pandemics and the emerging stock markets, Borsa Istanbul Review, 20(1), 40-48. https://doi.org/10.1016/j.bir.2020.11.004

Topcu, M., and Gulal, O. S. 2020. The impact of COVID-19 on emerging stock markets, Finance Research Letters, 36, 101691. https://doi.org/10.1016/j.frl.2020.101691

World Health Organization (2020). Coronavirus disease 2019 (COVID-19): situation report, 94, retrieved from: https://www.who.int/emergencies/diseases/novel-coronavirus2019/situation-reports

Zhang, D., Hu, M., and Ji, Q. (2020). Financial markets under the global pandemic of COVID19. Finance Research Letters, 36, 101528. https://doi.org/10.1016/j.frl.2020.101528 